TAZKIYA (Jurnal of Psychology)

D0l: http://dx.doi.org//0.15408/tazkiya.v9i2.17196

http://journal.uinjkt.ac.id/index.php/tazkiya

\title{
The Relationship of Self Regulated Learning with Academic Adjustment of Seventh Grade Santri of Pondok Pesantren
}

\author{
Ulfah Hannani, Clara Ajisuksmo \\ Fakultas Psikologi, Universitas Katolik Atma Jaya, Indonesia \\ uhannaniI7@gmail.com
}

\begin{abstract}
Academic adjustment is an important thing for students, especially seventh graders at Miftahul Ulum Islamic Boarding School, one of the modern-based Islamic boarding schools that combines the national education curriculum and the cottage curriculum. In early adolescence, students have begun to develop cognitive strategies and adjust behavior to the academic environment. The ability of students to regulate cognitive and behavior in learning is called self-regulated learning. The purpose of this study was to determine the relationship between self-regulated learning and the academic adjustment amongst seventh grade students of Miftahul Ulum Islamic Boarding School. The research method used in this research was mixed methods. Quantitative data was collected from 160 students through The Motivated Strategies of Learning Questionnaire Scale (MSLQ) to measure self-regulated learning and Student Adaptation to College Questionnaire (SACQ) to measure academic adjustment. While in the qualitative approach, group interviews students were conducted into three group based on the level of the self-regulated learning group and academic adjustment. The result reveals that there was a significant positive relationship between self-regulated learning and the academic adjustment of seventh grade students at Miftahul Ulum Islamic Boarding School ( $\mathrm{r}=$ $0,561 ; p<0,001)$ indicating that students who had high self-regulated learning also had high academic adjustment at Miftahul Ulum Islamic Boarding School. The group discussion found interesting results where students who have good motivation, cognitive strategies and learning behavior strategies, then adjust themselves to academic demands at Miftahul Ulum Islamic Boarding School is also good.
\end{abstract}

Keywords: self regulated learning, academic adjustment, boarding school, new student

\begin{abstract}
Abstrak
Penyesuaian akademik merupakan hal yang penting dimiliki oleh santri, khususnya santri baru kelas tujuh di Pondok Pesantren Miftahul Ulum, salah satu pondok pesantren berbasis modern yang memadukan antara kurikulum pendidikan nasional dan kurikulum pondok. Pada masa remaja awal, santri sudah mulai mengembangkan strategi kognitif dan menyesuaikan perilaku dengan lingkungan akademik. Kemampuan santri untuk mengatur kognitif dan perilaku dalam belajar disebut self-regulated learning. Tujuan dari penelitian ini adalah untuk menguji hubungan antara self-regulated learning dengan penyesuaian akademik santri kelas tujuh Pesantren Miftahul Ulum. Metode penelitian yang digunakan dalam penelitian ini adalah metode campuran. Data kuantitatif dikumpulkan dari 160 santri melalui The Motivated Strategies of Learning Questionnaire Scale (MSLQ) untuk mengukur self regulated learning dan Student Adaptation to College Questionnaire (SACQ) untuk mengukur penyesuaian akademik. Sedangkan pada pendekatan kualitatif, wawancara kelompok santri dilakukan menjadi tiga kelompok berdasarkan kategori self regulated learning dan penyesuaian akademik. Hasil penelitian menunjukkan bahwa terdapat hubungan positif yang signifikan antara self regulated learning dengan penyesuaian akademik santri kelas tujuh Pondok Pesantren Miftahul Ulum $(r=0,561 ; p$ $<0,001)$ yang menunjukkan bahwa santri yang memiliki self regulated learning tinggi juga memiliki penyesuaian akademik yang tinggi di Pesantren Miftahul Ulum. Diskusi kelompok menemukan hasil yang menarik di mana santri yang memiliki motivasi, strategi kognitif dan strategi perilaku belajar yang baik, maka penyesuaian diri terhadap tuntutan akademik di Pesantren Miftahul Ulum juga baik.
\end{abstract}

Kata-kata kunci: self regulated learning, penyesuaian akademik, pondok pesantren, santris baru 


\section{Pendahuluan}

Belajar di pondok pesantren berbasis modern berbeda dengan belajar di sekolah umum. Perpaduan kurikulum nasional dan kurikulum pondok membuat para santri khususnya kelas tujuh dituntut untuk mampu menyesuaikan diri dengan tuntutan-tuntutan akademik. Salah satu pondok pesantren modern adalah Pondok Pesantren Miftahul Ulum, Jakarta. Pondok Pesantren Miftahul Ulum memiliki dua kurikulum, yaitu kurikulum nasional dan kurikulum pondok. Mata pelajaran yang berada di dalam kurikulum nasional meliputi Ilmu Pengetahuan Alam, Ilmu Pengetahuan Sosial, Pendidikan Kewarganegaraan, Matematika, dan Bahasa Indonesia. Sedangkan, mata pelajaran yang ada di dalam kurikulum pondok meliputi Nahwu-Shorof (ilmu yang mempelajari kaidah-kaidah tata bahasa Arab), Tauhid (ilmu ketuhanan), Fiqih (ilmu yang mempelajari hukum syariat Islam), Akhlak, Tajwid (ilmu yang mempelajari tata bacaan al-Quran), serta al-Quran dan Hadist. Buku pelajaran yang ada dalam kurikulum pondok sebagian besar menggunakan Bahasa Arab. Selain itu, santri kelas tujuh juga diwajibkan menambah kosa kata Bahasa Arab dan Inggris setiap harinya. Hal itu disebabkan pada hari-hari tertentu santri diharuskan menggunakan Bahasa Arab dan Inggris dalam kesehariannya. Santri kelas tujuh juga diharuskan untuk dapat membaca al-Quran dengan baik, mampu menghafal kaidah-kaidah tata bahasa Arab (Ilmu Nahwu Shorof), serta menghafal kalimat indah dalam Bahasa Arab (mahfudzot). Sementara itu, sebagian besar santri baru di Pondok Pesantren Miftahul Ulum berasal dari Sekolah Dasar Negeri (SDN), di mana di jenjang pendidikan tersebut, mereka belum mendalami pembelajaran agama lebih mendalam. Sedangkan di Pondok Pesantren Miftahul Ulum pembelajaran agama menggunakan buku Bahasa Arab.

Selain itu, peraturan dan kegiatan belajar yang dilakukan di dalam pondok pesantren juga sangat beragam, mulai dari kegiatan sekolah, kegiatan belajar di pondok, ekstrakurikuler, serta organisasi sekolah. Padatnya jadwal yang harus diterima oleh santri, menuntut santri untuk dapat mengatur jadwal belajar secara mandiri. Tingginya beban akademik, dan padatnya jadwal belajar di Pondok Pesantren, membuat santri kelas tujuh menghadapi kesulitan dalam mengikuti pembelajaran seperti kesulitan dalam menghafal pelajaran, menghafal al-Quran, serta memahami pelajaran yang menggunakan Bahasa Arab. Sehingga, santri merasa cemas ketika menghadapi ujian, serta memilih untuk menghindari pembelajaran di Pondok Pesantren. Tidak sedikit santri yang nilainya berada di bawah Kriteria Ketuntasan Minimal (KKM), bolos mengikuti pelajaran, bahkan santri ingin kabur karena merasa tidak betah belajar di pondok pesantren. Menurut Zhen Rui (2014) ketidakmampuan individu dalam menyelesaikan tugas-tugas akademik disebabkan karena individu tersebut memiliki penyesuaian akademik yang kurang. Penyesuaian akademik merujuk pada cara santri mengatasi berbagai jenis tuntutan akademik. Santri dikatakan memiliki penyesuaian akademik jika mereka memiliki motivasi untuk menyelesaikan tugas akademik, berusaha dalam belajar, sukses dalam syarat akademik, dan memperoleh kepuasan dalam lingkungan akademik (Baker \& Siryk, 1989).

Berdasarkan penelitian sebelumnya terhadap santri kelas tujuh di Pondok Pesantren, dikatakan bahwa santri dengan penyesuaian akademik yang tinggi cenderung akan terus berusaha maksimal dalam menghadapi kesulitan terkait tugas-tugas yang menjadi tanggung jawabnya, gigih, dan mampu mencari alternatif jalan keluar dari masalah yang dihadapi. Sedangkan siswa dengan penyesuaian akademik yang rendah, akan memandang tugas-tugas akademik yang diberikan sebagai hal yang sulit untuk diselesaikan dan memilih menyerah karena tidak mampu untuk menyelesaikannya, tidak mampu menuntaskan hafalan, tidak mampu menguasai bahasa asing dengan maksimal, menolak mengikuti aturan di pondok pesantren, memilih menghindari kesulitan atau tugas yang diberikan, serta sering mendapatkan hukuman (Novadelian, 2017). 
Hasil penelitian Yuniar (2014) menunjukkan bahwa setiap tahunnya 5-10\% dari santri baru di Pondok Pesantren Assala Surakarta mengalami masalah dalam melakukan proses penyesuaian akademik, seperti tidak mampu mengikuti pelajaran, serta melakukan berbagai tindakan yang melanggar tata tertib pondok. Selain itu, penelitian tentang penyesuaian akademik di lingkungan pondok pesantren oleh Hendriani (2013) juga menemukan bahwa siswa yang kurang mampu menyesuaikan diri secara akademik pada umumnya menampilkan berbagai perilaku menyimpang seperti tidak mengerjakan tanggung jawabnya, tidak hadir pada pelajaran di kelas atau tidak konsentrasi pada penjelasan guru, tidak menunjukkan minat, serta tidak berpartisipasi dalam kelompok. Menurut Gunarsa (2012) siswa dengan penyesuaian akademik yang rendah cenderung kurang menampilkan kemampuan dirinya, menarik diri dari lingkungan, menghadapi kesulitan dalam bergaul dengan orang-orang di sekitarnya, memiliki tidak banyak teman, serta merasa rendah diri. Suasana psikologis tersebut menjadi sebab individu melupakan tanggung jawabnya, sehingga dapat berpengaruh terhadap prestasinya.

Jika dilihat tahapan perkembangannya, secara umum usia siswa kelas tujuh berada pada rentang usia 12-13 tahun. Usia tersebut merupakan satu periode dalam rentang hidup siswa yang tergolong masa remaja awal. Pada usia remaja awal, siswa sudah mulai mengembangkan strategi kognitif dan menyesuaikan perilaku dengan lingkungan akademik, misalnya dengan menganalisa masalah dari berbagai perspektif, membuat prediksi (hipotesis), kemudian mempertimbangkan beberapa opsi satu per satu sebelum sampai pada kesimpulan (formal operational thinking). Selanjutnya, siswa juga mampu berpikir secara abstrak tentang isu-isu kompleks, merencanakan dan mengatur kegiatan tanpa bantuan orang dewasa, menyukai tantangan akademik yang ada di sekolah, serta mulai membuat beberapa rencana untuk masa depan (Marrotz, 2013). Oleh karena itu, pentingnya mengembangkan strategi kognitif, dan perilakunya dalam belajar agar dapat berkembang seoptimal mungkin. Kemampuan siswa dalam mengatur kognitif dan perilaku dalam belajar disebut dengan self regulated learning (Anitei, 2010). Menurut Pintrich dan Groot (1990) self regulated learning merupakan sebuah proses konstruktif di mana pembelajar secara mandiri menetapkan tujuan belajarnya, kemudian memonitor perkembangannya, melakukan regulasi atau pengaturan kemudian melakukan kontrol secara kognitif, memotivasi tingkah laku, yang dituntun dan diarahkan oleh tujuan dan lingkungan di mana individu tersebut berada.

Penelitian Jansen dan Grift (2018) menemukan bahwa siswa yang memiliki self-regulated learning menampilkan perilaku yang dapat mengatur waktu belajar dengan baik, mandiri, serta bertanggung jawab terhadap tugas yang diberikan, sehingga lebih mudah dalam menyesuaikan diri dengan tuntutan akademik. Selain itu, penelitian Cazan (2012) juga menyatakan bahwa siswa yang memiliki perencanaan belajar secara efisien, memantau kemajuan belajar, dan secara terus menerus berusaha menyesuaikan perilaku mereka terhadap tuntutan belajar yang ada. Rooij (2017) dalam penelitianya menemukan bahwa kapasitas regulasi diri (self regulated learning) berperan penting dalam menentukan kesuksesan penyesuaian akademik para mahasiswa di perguruan tinggi.

Menurut Pintrich dan Groot (1990) self regulated learning memiliki dua komponen yaitu komponen motivasional dan komponen kognitif. Komponen motivasional terdiri dari tiga sub komponen yaitu keyakinan diri akademik, nilai intrinsik dan reaksi emosi. Sedangkan komponen kognitif terdiri dari dua sub komponen yaitu strategi kognitif dan strategi tingkah laku. Siswa dikatakan memiliki self regulated learning jika mereka memiliki keyakinan akan kemampuannya dalam belajar, keyakinan akan pentingnya tugas yang diberikan, serta dapat memelihara emosi positif selama mengerjakan tugas akademik. Selain itu, siswa yang memiliki self regulated learning juga memiliki metode yang digunakan untuk mengembangkan pemahaman, serta mengintegrasikan informasi baru yang mereka terima dalam proses pembelajaran. Selanjutnya, mereka juga memiliki cara yang dapat digunakan untuk meminimalisasi 
hambatan dalam proses belajar, misalnya dengan mencari bantuan jika tidak memahami materi, melakukan manajemen waktu yang efektif, serta membentuk lingkungan belajar yang kondusif.

Berdasarkan latar belakang inilah, peneliti tertarik untuk melihat hubungan antara self-regulated learning dengan penyesuaian akademik santri Pondok Pesantren Miftahul Ulum. Jika penelitian sebelumnya sebagian besar melihat hubungan self regulated learning dan penyesuaian akademik mahasiswa di perguruan tinggi, pada penelitian ini, peneliti ingin melihat hubungan antara kedua variabel tersebut dalam konteks pondok pesantren. Topik ini penting untuk diteliti karena mengingat pondok pesantren merupakan salah satu lembaga pendidikan yang memiliki kekhasan tersendiri jika dibandingkan institusi pendidikan lainnya. Selain itu, baik atau tidaknya self-regulated learning dan penyesuaian akademik yang dilakukan oleh santri kelas tujuh di Pondok Pesantren Miftahul Ulum, tentunya akan menentukan hubungannya dengan lingkungannya yang berada di pondok pesantren, sehingga santri dapat memaksimalkan potensinya dalam belajar.

\section{Metode Penelitian}

Penelitian ini menggunakan pendekatan mixed method. Yaitu metode penelitian yang menggabungkan antara metode kuantitatif dengan metode kualitatif di dalam satu penelitian agar mendapatkan data yang lebih komprehensif, valid, reliabel, dan objektif. Pengumpulan data penelitian kuantitatif dilakukan dengan menggunakan alat ukur berupa kuesioner dengan bentuk skala Likert dengan pilihan penilaian dari setiap item jawaban berkisar antara 1-4. Alat ukur yang digunakan dalam penelitian ini translasi dan adaptasi dari The Motivated Strategies of Learning Questioner Scale (MSLQ; Pintrich \& Groot, 1990) terdiri dari 44 item untuk mengukur self regulated learning dan Student Adaptation to College Questionnaire (SACQ; Baker \& Siryk, 1989) terdiri dari 24 item untuk mengukur penyesuaian akademik. Pada pengujian validitas alat ukur MSLQ koefisien korelasi item total bergerak dari 0,210 sampai dengan 0,749. Hasil reliabilitas alat ukur self regulated learning (MSLQ) dengan menggunakan Cronbach Alpha adalah sebesar 0,864 . Selanjutnya pada pengujian validitas alat ukur penyesuaian akademik (SACQ) korelasi item total bergerak dari 0,222 sampai dengan 0,779. Hasil reliabilitas alat ukur penyesuaian akademik (SACQ) dengan menggunakan Cronbach Alpha adalah sebesar 0,858. Hasil tersebut menggambarkan alat ukur MSLQ dan SACQ dapat digunakan untuk mengukur self regulated learning dan penyesuaian akademik terhadap santri kelas tujuh di Pondok Pesantren Miftahul Ulum.

Pengambilan data kualitatif dalam penelitian ini menggunakan wawancara kelompok. Wawancara kelompok dilakukan kepada kelompok santri yang memiliki self regulated learning dan penyesuaian akademik yang tergolong tinggi dan rendah. Berikut panduan wawancara kelompok yang digunakan dalam penelitian ini.

Tabel 1. Panduan Wawancara Kelompok Self Regulated Learning

\begin{tabular}{ll}
\hline Komponen & Pertanyaan \\
\hline Motivasional & - Bagaimana usaha Anda agar dapat memahami materi yang \\
& diberikan? \\
& - Usaha apa yang Anda lakukan, agar dapat berhasil menjalani ujian di \\
& Pondok Pesantren? \\
\hline Kognitif & - Bagaimana caramu agar dapat memahami bacaan? \\
& - Apakah kamu membuat kesimpulan bacaan? Bagaimana caranya? \\
& - Apakah kamu mencatat hal-hal penting ketika membaca? \\
\hline
\end{tabular}


- Apakah kamu membuat perencanaan mengenai apa yang perlu dilakukan? Bagaimana kamu melaksanakan perencanaan tersebut?

- Bagaimana cara yang kamu lakukan, agar dapat mudah memahami materi yang diberikan?

\begin{tabular}{|c|c|}
\hline \multicolumn{2}{|c|}{ Tabel 2. Panduan Wawancara Kelompok Penyesuaian Akademik } \\
\hline Aspek & Pertanyaan \\
\hline Motivation & $\begin{array}{l}\text { - Apakah alasan kamu masuk ke pondok pesantren } \\
\text { pesantren? } \\
\text { - Apakah tujuan belajarmu di pesantren? } \\
\text { - Apa harapanmu setelah keluar dari pesantren? }\end{array}$ \\
\hline Application & $\begin{array}{l}\text { - Bagaimana kamu mengatur waktu belajar di } \\
\text { pesantren? } \\
\text { - Bagaimana cara yang kamu lakukan dalam } \\
\text { memahami materi pelajaran selama ini? } \\
\text { - Bagaimana usaha belajar yang kamu lakukan agar } \\
\text { dapat menyesuaikan dengan pelajaran di sekolah? }\end{array}$ \\
\hline Performance & $\begin{array}{l}\text { - Bagaimana pendapatmu mengenai belajarmu selama } \\
\text { ini? } \\
\text { - Apakah kamu merasa dapat mengikuti pelajaran } \\
\text { yang diberikan? } \\
\text { - Bagaimana cara yang kamu lakukan, jika } \\
\text { mengalami kesulitan dalam suatu pelajaran? }\end{array}$ \\
\hline Academic Environment & $\begin{array}{l}\text { - Bagaimana menurut pendapatmu mengenai suasana } \\
\text { belajar di pondok pesantren? } \\
\text { - Bagaimana menurut pendapatmu mengenai fasilitas } \\
\text { belajar yang ada di pondok pesantren? Apakah } \\
\text { mendukung dalam proses belajar mengajar? } \\
\text { - Bagaimana pendapatmu mengenai cara guru } \\
\text { mengajar di kelas? }\end{array}$ \\
\hline
\end{tabular}

Teknik analisis data kuantitatif yang digunakan adalah teknik statistik korelasi Spearman's Correlation. Sebelum melakukan analisis dengan teknik korelasi Spearman's Correlation, peneliti melakukan uji normalitas terlebih dahulu. Dalam penelitian ini, analisis dilakukan dengan bantuan perangkat lunak SPSS versi 22.00. Sedangkan analisi data kualitatif menggunakan metode content analysis.

\section{HASIL}

Data Demografis Partisipan

Jumlah partisipan yang terlibat dalam penelitian ini adalah sebanyak 160 santri kelas tujuh di Pondok Pesantren Miftahul Ulum. Berikut adalah data demografis dari partisipan penelitian ini:

Tabel 3. Data Demografis Partisipan

\begin{tabular}{llll}
\hline Kategori & Data Demografis & Frekuensi & Persentase (\%) \\
\hline
\end{tabular}


TAZKIYA (Journal of Psychology), 9(2), 2021

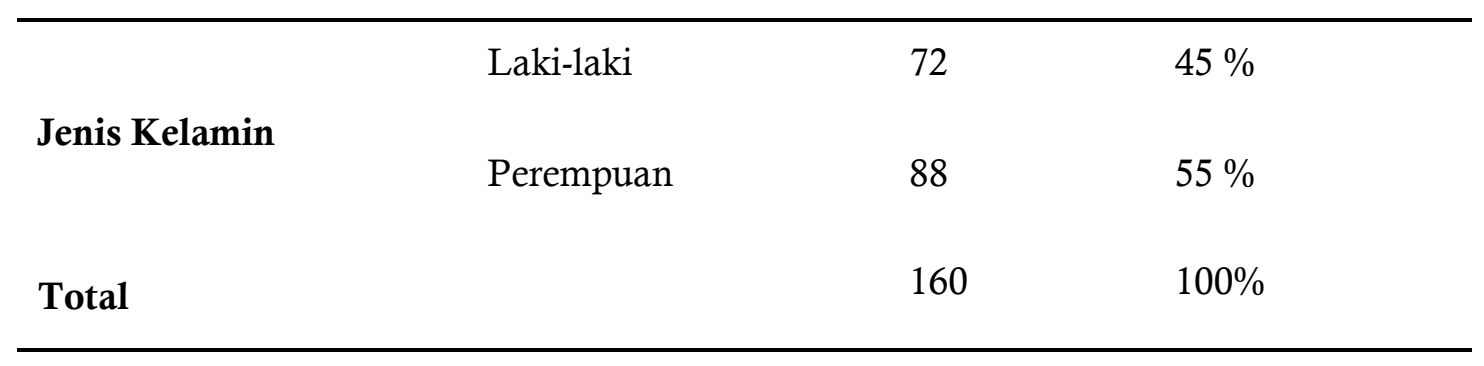

Deskirpsi Data Penelitian

Berdasarkan hasil data karakteristik subjek penelitian, diketahui bahwa sebesar 55\% partisipan dalam penelitian ini adalah perempuan, sedangkan partisipan laki-laki berjumlah $45 \%$.

Selanjutnya, berdasarkan perolehan data terhadap 160 partisipan, berikut merupakan gambaran statistik dari setiap variabel yang sudah dibagi dengan jumlah item.

Tabel 4. Deskripsi Data Penelitian

\begin{tabular}{llllll}
\hline Komponen & Mean & Std. Deviasi & Min & Max & N \\
\hline $\begin{array}{l}\text { Self Regulated } \\
\text { Learning }\end{array}$ & 2,53 & 0,33 & 1,40 & 3,70 & 160 \\
\hline $\begin{array}{l}\text { Penyesuaian } \\
\text { Akademik }\end{array}$ & 2,83 & 0,26 & 2,08 & 3,50 & 160 \\
& & & & & \\
\hline
\end{tabular}

Berdasarkan tabel 4, rata-rata nilai self regulated learning sebesar 2,53 kemudian diikuti oleh penyesuaian akademik sebesar 2,83. Hal tersebut mengindikasikan bahwa variabel tersebut memiliki skor yang sedang.

\section{Uji Normalitas}

Sebelum melakukan uji korelasi antara kedua variabel, peneliti melakukan uji normalitas dari kedua alat ukur, yaitu The Motivated Strategies of Learning Questioner Scale (MSLQ) dan Student Adaptation to College Questionnaire (SACQ). Hal ini dilakukan untuk menentukan teknik statistik yang tepat untuk melakukan pengujian korelasi antara kedua variabel. Adapun hasil uji normalitas adalah sebagai berikut:

Tabel 5. Hasil Uji Nomalitas

\begin{tabular}{llll}
\hline Variabel & Kolmograv-Smirnov & & \\
& Statistic & df & Sig. \\
\hline Self Regulated Learning & 0,984 & 160 & 0,071 \\
Penyesuaian Akademik & 0,979 & 160 & 0,017 \\
\hline
\end{tabular}

Berdasarkan dari pemaparan hasil uji normalitas pada tabel 5 di atas, menunjukkan bahwa persebaran data alat ukur The Motivated Strategies of Learning Questioner Scale (MSLQ) normal, dengan nilai 
signifikansi 0,071 ( $\mathrm{p}>0,05)$, sedangkan untuk persebaran data Student Adaptation to College Questionnaire (SACQ) tidak normal, dengan nilai signifikansi $0,017(\mathrm{p}<0,05)$. Oleh sebab uji normalitas menyatakan bahwa ada salah satu variabel memiliki persebaran data yang tidak normal, maka peneliti akan menggunakan teknik Spearman Correlation untuk menguji hubungan kedua variabel karena tidak sesensitif Person Correlation terkait keberadaan outliers.

\section{Uji Hipotesis}

Berdasarkan uji Spearman ditemukan hasil yang bisa dilihat sebagaimana tabel 6:

Tabel 6. Uji Korelasi Spearman's Self Regulated Learning dengan Penyesuaian Akademik

\begin{tabular}{lllllll}
\hline Variabel & & & & r & Sig. $(p)$ & n \\
\hline $\begin{array}{l}\text { Self Regulated } \\
\text { Akademik }\end{array}$ & Learning & dan & Penyesuaian & $0,561^{* *}$ & 0,000 & 160 \\
\hline
\end{tabular}

Berdasarkan hasil perhitungan pada tabel 12, dapat dikatakan bahwa hasil uji korelasi dengan menggunakan teknik statistik spearman correlation menunjukkan nilai $p<0,001$. Dari nilai tersebut, dapat disimpulkan bahwa Ho ditolak. Artinya, terdapat hubungan yang signifikan antara self regulated learning dengan penyesuaian akademik pada santri kelas tujuh di Pondok Pesantren Miftahul Ulum. Dari nilai $\mathbf{r}$ dapat diketahui bahwa hubungan yang ada antara kedua variabel memiliki arah yang positif. Maka, dapat dikatakan bahwa semakin tinggi self regulated learning, maka semakin tinggi tingkat penyesuaian akademik santri kelas tujuh di Pondok Pesantren Miftahul Ulum. Adapun sumbangan self regulated learning terhadap penyesuaian akademik sendiri adalah $r^{2}=0,31$ atau $31,47 \%$.

\section{Analisa Data Demografis}

Selanjutnya peneliti juga melakukan analisis berdasarkan data demografis. Analisis ini dilakukan untuk mengelaborasikan data demografis dengan self regulated learning dan penyesuaian akademik. Data demografis yang digunakan untuk melakukan analisis tambahan adalah jenis kelamin. Berdasarkan berbagai hal tersebut di atas, maka peneliti melakukan analisa lebih lanjut yang hasilnya dapat dilihat pada tabel 7, sebagai berikut:

Tabel 7. Analisa Data Demografis

\begin{tabular}{llll}
\hline Variabel & Data Demografis & Signifikansi (<.05) & Keterangan \\
Self Regulated Learning & Jenis Kelamin & Tidak Signifikan & $\begin{array}{l}\text { Tidak ada perbedaan } \\
\text { self regulated learning }\end{array}$ \\
& & & antara santri laki-laki \\
& & dan santri perempuan \\
Penyesuaian Akademik & Tidak Signifikan & Tidak ada perbedaan \\
& & penyesuaian akademik
\end{tabular}


Berdasarkan hasil pengujian, dapat disimpulkan bahwa dari aspek demografis jenis kelamin, tidak ada nilai yang signifikan dalam mempengaruhi self regulated learning, dan penyesuaian akademik.

\section{Wawancara Kelompok}

Selanjutnya berdasarkan hasil wawancara yang dilakukan, dapat dilihat bahwa kelompok santri yang memiliki self regulated learning (regulasi diri dalam belajar) tinggi, maka penyesuaian akademik yang dimiliki juga tinggi. Hal tersebut terlihat dari motivasi yang dimiliki santri untuk berprestasi, seperti adanya keyakinan akan kemampuannya dalam mengikuti pembelajaran, memiliki tujuan belajar, serta dapat mengatur emosi selama pembelajaran. Selain motivasi, kemampuan santri dalam self regulated learning (regulasi diri dalam belajar) juga terlihat dari strategi kognitif dan tingkah laku yang dilakukan selama pembelajaran. Dalam hal ini, strategi kognitif yang digunakan seperti merangkum, memahami, mengingat, mengelaborasi serta melakukan pengulangan. Strategi tingkah laku yang dilakukan santri di antaranya seperti melakukan perencanaan belajar. Perencanaan belajar yang dilakukan oleh santri yaitu dengan mengatur waktu belajar dengan baik, seperti mempelajari materi ujian jauh hari sebelum ujian. Santri berusaha memahami pelajaran dengan bertanya kepada guru, teman, maupun kakak senior di asrama.

Kemampuan santri mengatur diri dalam belajar, menjadikan santri dapat menyesuaikan diri dengan tuntutan akademik yang ada di Pondok Pesantren Miftahul Ulum. Hal ini terlihat dari perilaku santri yang termotivasi dalam mengerjakan tugas-tugas yang diberikan. Meskipun merasa sulit, santri berusaha mencari informasi terkait tugas yang diberikan. Selain itu, nilai yang dihasilkan juga berada di atas KKM (Kriteria Ketuntasan Minimal). Santri juga memiliki penilaian yang baik terhadap Pondok Pesantren Miftahul Ulum.

Selanjutnya, kelompok santri yang memiliki self regulated learning (regulasi diri dalam belajar) rendah, maka penyesuaian akademik yang dimiliki juga rendah. Hal tersebut terlihat dari kurangnya motivasi santri untuk berprestasi di Pondok Pesantren Miftahul Ulum. Para santri belum memahami tujuan belajarnya di Pondok Pesantren Miftahul Ulum, serta merasa kurang yakin dengan kemampuannya dalam belajar. Sehingga perilaku yang ditampilkan seperti tidak mengerjakan tugas dari guru, tidak melakukan persiapan belajar untuk ujian, serta cenderung pasrah jika tidak memahami materi pelajaran. Perilaku santri tersebut berdampak pada hasil belajar di Pondok Pesantren Miftahul Ulum yang sebagian besar berada di bawah KKM. Pada kelompok santri yang memiliki self regulated learning dan penyesuaian akademik pada kategori sedang mengatakan bahwa dirinya belum memiliki tujuan dalam belajar, serta belum yakin akan kemampuannya dalam belajar seperti saat mempelajari mata pelajaran Bahasa Arab, Matematika, dan IPS. Meskipun demikian, santri masih berusaha agar dapat menjalani tuntutan akademik yang ada di Pondok Pesantren, yaitu dengan belajar ketika menghadapi ujian, serta mengerjakan tugas yang diberikan guru. Cara belajar yang selama ini dilakukan yaitu dengan menggaris bawahi materi yang sedang dipelajari, kemudian dihafalkan. Namun, cara tersebut dirasa belum efektif. Hal tersebut terlihat dari nilai yang masih berada di bawah KKM, pada beberapa mata pelajaran tertentu. Kesulitan yang dihadapi santri di pondok pesantren Miftahul Ulum, yaitu dalam mengatur waktu untuk belajar. Santri merasa sulit untuk bisa fokus dalam belajar di Pondok Pesantren Miftahul Ulum, karena harus berbagi tempat belajar dengan teman lain.

Hasil data kualitatif sejalan dengan data kuantitatif yang menunjukkan adanya hubungan antara self regulated learning dengan penyesuaian akademik santri di Pondok Pesantren Miftahul Ulum. Jika dilihat dari komponen yang dimiliki self regulated learning, terlihat bahwa pada komponen motivasi dan kognitif memang berhubungan dengan penyesuaian akademik santri. Bagi para santri yang memiliki motivasi 
dalam dirinya untuk belajar serta memiliki strategi belajar yang baik akan membantu santri dalam menyesuaikan diri dengan tuntutan akademik yang ada di Pondok Pesantren Miftahul Ulum. Hal ini tergambar pada kelompok santri kategori tinggi, rendah, dan sedang, di mana dorongan dalam diri untuk belajar serta strategi kognitif dan tingkah laku membantu santri baru dalam menjalankan tuntutan akademik di Pondok Pesantren.

\section{Diskusi}

Kajian ini bertujuan untuk menguji hubungan antara self regulated learning dengan penyesuaian akademik santri kelas tujuh pada Pondok Pesantren Miftahul Ulum. Hasil analisis terhadap data penelitian menunjukkan bahwa ada hubungan signifikan antara self regulated learning dengan penyesuaian akademik pada santri kelas tujuh di Pondok Pesantren Miftahul Ulum. Temuan ini sejalan dengan penelitian Rooij (2017) terhadap mahasiswa tahun pertama di perguruan tinggi yang menunjukkan bahwa siswa yang memiliki keterampilan dalam mengatur pikiran, perasaan dan perilakunya dalam belajar (self regulated learning) akan memiliki penyesuaian akademik yang baik di sekolah, sehingga siswa memiliki prestasi akademik yang baik. Pernyataan ini diperkuat juga dengan hasil penelitian Cazan (2012) terhadap mahasiswa tahun pertama perguruan tinggi di Transylvania menunjukkan bahwa siswa yang merencanakan proses belajar, memantau kemajuan belajar, serta menyesuaikan perilaku mereka pada situasi belajar akan berkinerja lebih baik dan memiliki tingkat penyesuaian akademik yang lebih tinggi.

Selain itu, hasil penelitian ini juga sejalan dengan penelitian yang dilakukan Cazan (2012) yang menyatakan bahwa keyakinan akan kemampuan diri yang merupakan bagian dari self regulated learning merupakan hal yang penting dimiliki oleh siswa pada tahun pertama ketika mereka menyesuaikan diri dengan lingkungan akademik yang baru. Penelitian yang dilakukan oleh De Clercq (2017) menyatakan bahwa nilai intrinsik yang menjadi salah satu komponen self regulated learning juga memiliki hubungan dengan penyesuaian akademik. Siswa yang memiliki motivasi untuk mempelajari suatu materi bukan hanya karena ingin mendapat nilai yang baik, dan memiliki keyakinan akan pentingnya mempelajari suatu materi akan lebih terlibat secara kognitif dalam mempelajari dan memahami materi.

Penelitian lain yang sejalan yaitu dilakukan oleh Jacobsen dan Forste (2011) menyatakan bahwa usaha dalam mengatur waktu dan menciptakan lingkungan yang kondusif dalam belajar akan memudahkan siswa dalam menyesuaikan diri dengan tuntutan akademik, yang berdampak pada prestasi akademik di sekolah. Begitujuga dengan penelitian sebelumnya yang dilakukan oleh Jansen dan Suhre (2010) yang menyatakan bahwa siswa yang mencoba memahami pelajaran dengan menghafal, mengatur, dan mentransformasikan materi di kelas dengan melakukan pengulangan, elaborasi dan organisasi akan menunjukkan performa akademik yang baik.

Berdasarkan hasil kualitatif didapatkan dari wawancara kelompok yang dilakukan kepada kelompok self regulated learning dan penyesuaian akademik kategori tinggi ditemukan bahwa self regulated learning berhubungan dengan tingkat penyesuaian akademik santri kelas tujuh di Pondok Pesantren Miftahul Ulum. Hal tersebut terlihat dari motivasi santri kelas tujuh untuk berprestasi, seperti santri memiliki keyakinan bahwa ia mampu dalam menjalani pembelajaran di Pondok Pesantren Miftahul Ulum, memiliki keyakinan akan pentingnya suatu tugas yang diberikan, serta dapat mengatur emosinya ketika diberikan tugas. Selain motivasi, kemampuan siswa dalam self regulated learning (regulasi diri dalam belajar) juga terlihat dari strategi kognitif dan tingkah laku yang dilakukan selama pembelajaran. Siswa yang sudah memahami strategi kognitif dan tingkah laku efektif yang ia gunakan dalam memahami, mengintegrasikan informasi yang didapatkannya, mengatur waktu belajar, serta menemukan lingkungan belajar yang 
kondusif lebih mampu menyesuaikan diri dengan tuntutan akademik yang diberikan. Hal tersebut juga tampak dari nilai yang didapatkan siswa yang tergolong baik.

Selain itu, santri yang memiliki self regulated learning yang rendah, maka santri akan mengalami kesulitan dalam menjalani tuntutan akademik di Pondok Pesantren. Kurangnya motivasi untuk berprestasi, serta belum memahami tujuan belajar di Pondok Pesantren Miftahul Ulum, membuat santri merasa kurang yakin atas kemampuannya dalam belajar. Hal tersebut memiliki dampak pada hasil belajar santri di Pondok Pesantren Miftahul Ulum yang berada di bawah KKM. Hal ini sejalan dengan penelitian yang dilakukan oleh Zimmerman (dalam Clearly, 2014) yang menyatakan bahwa ketidakefektifan santri dalam menentukan strategi self regulated learning dapat menimbulkan gangguan dalam penyesuaian akademik di sekolah seperti tidak memperhatikan di kelas, kegagalan dalam mempersiapkan diri menjelang ulangan, bahkan tidak hadir di sekolah.

Selain self regulated learning, faktor yang mempengaruhi penyesuaian akademik santri di Pondok Pesantren Miftahul Ulum, yaitu dukungan sosial, dan interaksi dengan staf pengajar. Berdasarkan hasil penelitian menunjukkan bahwa variabel self regulated learning memberikan sumbangan sebesar $31.47 \%$, yang artinya ada $68.53 \%$ sumbangan pengaruh dari variabel lain. Dukungan sosial dari ustadz/ustadzah, maupun teman menjadi salah satu faktor yang mendukung santri dalam belajar di Pondok Pesantren Miftahul Ulum. Hal ini sejalan dengan pernyataan Friedlander (2010) yang menyatakan bahwa santri yang mendapatkan dukungan sosial lebih dapat menyesuaikan diri secara akademik dengan baik dan kurang merasa tertekan dalam belajar dibandingkan dengan mereka yang kurang mendapatkan dukungan. Selain itu, interaksi antara santri dengan guru juga menjadi faktor lainnya yang mendukung penyesuaian akademik santri kelas tujuh di Pondok Pesantren Miftahul Ulum. Frekuensi dan kualitas dari santri yang berdiskusi di luar kelas secara signifikan dan nyata berhubungan dengan pencapaian akademik.

Berdasarkan tugas perkembangan, secara umum usia santri kelas tujuh di Pondok Pesantren Miftahul Ulum berada pada rentang usia 12-13. Usia tersebut merupakan satu periode dalam rentang kehidupan santri yang tergolong masa remaja awal (Marrotz, 2013). Demi kepentingan belajar, maka kewajiban untuk tinggal menetap di lingkungan pondok pesantren menuntut santri untuk dapat menyesuaikan diri terhadap segala aktivitas, pelajaran, budaya dan kebiasaan yang ada di lingkungan pesantren, demi terciptanya lingkungan pesantren yang harmonis dan kondusif (Hendriani, 2013). Menurut Marotz (2013), pada usia remaja awal, siswa sudah mulai menganalisa masalah dari berbagai perspektif. Pertama membuat prediksi (hipotesis), kemudian mempertimbangkan beberapa opsi satu per satu sebelum sampai pada kesimpulan (formal operational thinking). Selanjutnya, siswa juga mampu berpikir secara abstrak tentang isu-isu kompleks, merencanakan dan mengatur kegiatan tanpa bantuan orang dewasa, menyukai tantangan akademik yang ada di sekolah, serta mulai membuat beberapa rencana untuk masa depan.

Berdasarkan hasil penelitian yang telah dilakukan dapat dikatakan bahwa santri masih menampilkan perilaku yang tampak belum sesuai dengan tugas perkembangan remaja awal. Santri masih menampilkan perilaku yang belum dapat melakukan perencanaan dengan baik secara kognitif maupun perilaku. Sebagai contoh ada santri yang belum memahami cara yang harus dilakukan agar dapat memahami materi pelajaran dengan baik. Santri juga belum dapat mengatur jadwal belajar tanpa bantuan orang dewasa di sekitarnya. Selain itu, santri juga belum memahami tujuan belajarnya di Pondok Pesantren Miftahul Ulum. Hal tersebut berdampak pada nilai yang didapatkan di Pondok Pesantren Miftahul Ulum yang masih berada di bawah KKM. Oleh karena itu, perlunya meningkatkan keterampilan santri kelas tujuh di Pondok Pesantren Miftahul Ulum dalam meregulasi diri dalam belajar (self regulated 
learning). Dengan meningkatnya self regulated learning diharapkan penyesuaian diri santri dalam menjalani segala tuntutan akademik pun menjadi lebih baik.

Penelitian ini menarik karena menjadi referensi tambahan terkait kajian masalah belajar santri pesantren modern yang harus menempuh dua kurikulum dalam satu saat bersamaan. Namun demikian penelitian ini juga memiliki keterbatasan diantaranya masih bersifat korelasional sehingga tidak dapat menjelaskan pengaruh ataupun hubungan sebab akibat.

\section{Kesimpulan}

Berdasarkan hasil pengolahan data yang telah dilakukan, dapat dikatakan bahwa hasil uji korelasi dengan menggunakan teknik statistik Spearman Correlation menunjukkan nilai $p=0.000(\mathrm{p}<0.05)$. Dari nilai tersebut dapat disimpulkan bahwa Ho ditolak. Artinya terdapat hubungan yang signifikan antara self regulated learning dengan penyesuaian akademik pada santri kelas tujuh di Pondok Pesantren Miftahul Ulum. Dari nilai $\mathrm{r}$ dapat diketahui bahwa hubungan yang ada antara kedua variable memiliki arah yang positif. Maka, dapat dikatakan bahwa semakin tinggi self regulated learning, maka semakin tinggi tingkat penyesuaian akademik santris kelas tujuh di Pondok Pesantren Miftahul Ulum.

Penelitian ini diharapkan dapat menjadi pertimbangan dalam melakukan upaya-upaya preventif terhadap terjadinya perilaku kurangnya penyesuaian akademik di pondok pesantren. Peneliti pun menyadari masih terdapat kekurangan di dalam penelitian ini. Peneliti memberikan saran sebagai pertimbangan demi pengembangan penelitian selanjutnya. Penelitian selanjutnya disarankan untuk melihat pengaruh antara variabel self regulated learning dengan penyesuaian akademik. Sehingga mampu memberikan intervensi dalam meningkatkan keterampilan santri dalam meregulasi diri dalam belajar berupa pelatihan.

\section{Daftar Pustaka}

Ali, M. (2015). Psikologi remaja. Bumi Aksara

Anastasi, A., \& Urbina. (2010). Tes Psikologi. PT Indeks.

Anitei, M. (2010). Motivation, learning strategies and academic adjustment. Romanian Journal of Experimental Applied Psychology, 1(1), 61-69

Anwar, A. (2016). Karakteristik Pendidikan dan Unsur-Unsur Kelembagaan di Pesantren. Jurnal Kependidikan Islam, 2(2), 165-181

Azwar, S. (2015). Penyusunan Skala Psikologi Edisi 2. Pustaka Pelajar.

Badu, S.Q. (2013). Implementasi Evaluasi Model Kirkpatrick Pada Perkuliahan Masalah Nilai Awal dan Syarat Batas. Jurnal Penelitian dan Evaluasi Pendidikan, 8(6), 102-129.

Baker, R.W., \& Siryk, B. (1989). The student adaptation to college questionnaire (SACQ). A WPS Test Report. Western Psychology Service

Bembenutty, H. (2010). Self regulation of learning and test anxiety. Psychology Journal, 5, 122-139 
Boekaerts, M. \& Niemivierta, M. (2010). Self regulated learning: Finding A Balance Between Learning Goals and Ego Protective Goals. Dalam M Boekaerts, P. R. Pintrich, \& M. Zeidner (Ed.). Handbook of Self Regulation. Academic Press.

Cazan, A.M. (2012). Self regulated learning strategies - Predictors of academic adjustment. Social and Behavioral Sciences, 8(2), 698-707

Christanto, S. T. (2015). "Hubungan Antara Adversity Intelligence Dengan Penyesuaian Akademik Pada Mahasiswa Universitas Esa Unggul". Skripsi. Fakultas Psikologi, Universitas Esa Unggul Jakarta Barat.

Cleary, Timothy J., Zimmerman, Barry J.(2014). Self Regulation Empowerment Program: A School Based Program to Enhance Self Regulated and Self Motivated Cycles of Student Learning. Psychology in the Schools, 41(5), 537-550

Cohen, R., Swerdlik, M. (2010). Psychological Testing and Asessment: an Introduction to test and Measurement. McGraw Hill

Cresswell, J. W. (2012). Research Design Qualitative, Quantitative And Mixed Methods Approaches. CA Sage.

De Clercq, M. (2017). Transition from high school to university: a person-centered approach to academic achievement. European Journal of Psychology of Education, 33, 39-59

Doolittle, Peter E.. (2010). Reciprocal Teaching for Reading Comprehension in Higher Education: A Strategy for Fostering the Deeper Understanding of Texts. International Journal of Teaching and Learning in Higher Education, 17(2), 106-118.

Fina, S. (2011). Pengaruh Self Efficacy terhadap Penyesuaian Akademik Mahasiswa. Jurnal Ilmiah Psikologi, 4(1), 289-304

Flick, U. (2009). An Introduction to Qualitative Research. SAGE Publications. $4^{\text {th }}$ ed.

Friedlander, L. J. (2010). Social Support, Self-Esteem, and Stress as Predictors of Adjustment to University Among First-Year Undergraduates. Journal of College Student Development Volume 48 Ed 3 , 256.

Gravetter, F.J., \& Wallnau, L.B. (2013). Statistics for behavioral sciences (9th Ed). Belmont,CA: Wadsworth, Cengage Learning.

Gunarsa, S.D. (2012). Psikologi Sosial I. Bandung: Eresco

Hamali, A.Y. (2016). Pemahaman Manajemen Sumber Daya Manusia. Center for Academic Publishing Service

Hendriani, W. (2013). Penyesuaian Akademik Remaja yang Tinggal di Pondok Pesantren Modern Nurul Izzah Gresik Pada Tahun Pertama. Jurnal Psikologi Kepribadian dan Sosial, 2(3), 141-150.

Hidayat, D.A.J. (2012). Perbedaan Penyesuaian Diri Santri di Pondok Pesantren Tradisional dan Modern. Talenta Psikologi, 1(2), 106-126

Jacobson, J.E. (2010). The impact of mothers' gender role stereotype beliefs on mothers' and children's ability perceptions. Journal of Personality and Social Psychology, 63, 932-944. 
Jacobsen, W.C., \& Forste, R. (2011). The wired generation: academic and social outcomes of electronic media use among university students. Cyberpsychology, Behavior and Social Networking, 14(5), 275-280

Jansen, E. P. W. A., \& Grift, W.J.C.M. (2018). First year university students' academic success: The Importance of academic adjustment. European Journal of Psychology of Education, 33(5), 749-767.

Jansen, E.P.W.A., \& Suhre, C.J.M. (2010). The effect of secondary school study skills preparation on first year university achievement. Educational Studies, 36(5), 569-580

Kaplan, R.M dan Saccuzzo, D.P. (2013). Psychological testing principles, application and issue. Sixth Edition. Wadsworth

Kline, Rex B., 2011. Principles and practice of structural equation modeling. Third Edition. The Guilford Press

Kumar, R. (2010). Research methodology: a step by step guide for beginners, Edisi Ketiga. Sage Publication

Kyalo, P.M. (2011). Selected Factors Influencing Social and Academic Adjustment of Undergraduate Students of Egerton University. International Journal of Business and Social Science, 2, 657-712.

Lapan, R.T., (2011). Career Development: Across the K-16 Years, Bridging the Present to Satisfying and Succesful Future. American Counseling Association, 22, 304

Mangkuprawira, T. S. (2004). Manajemen sumber daya manusia strategik. Ghalia Indonesia.

Marotz, L.R., \& Allen, K.E.(2013). Developmental profiles pre-birth through adolescence. Wadsworth Cengage Learning

Moleong, L. J. (2010). Metodologi penelitian kualitatif. Remaja Rosdakarya.

Mukhid, A. (2010). Strategi Self Regulated Learning (Perspektif Teoritik). Tadris, 3(2),223-239.

Mulyani, M.D. (2013). Hubungan antara manajemen waktu dengan self regulated learning. Educational Psychology Journal, 2(1), 43-48.

Nassazi, A. (2013). Effects of training on employee performance. Tesis. International Business Faculty, University Of Applied Sciences Uganda

Novadelian, A. (2017). Perbedaan penyesuaian akademik ditinjau dari ketagorisasi adversity intelligence pada santri MTs Pondok Pesantren Daar El Qolam 1 Jayanti.Tesis. Fakultas Psikologi Universitas Esa Unggul.

Ormrod, J.E. (2010). Educational Psychology: Developing Learners $6^{\text {th }}$ Ed. Pearson Education Inc.

Palinscar, A. S., \& Brown, A. L. (1984). Reciprocal teaching of comprehension-fostering and comprehensionmonitoring activities. Cognition and Instruction, 1(2), 117-175

Pintrich, P.R., De Groot, E.V. (1990). Motivational and Self regulated learning Component of Classroom Academic Performance. Journal of Educational Psychology, 82(1), 33-40.

Pintrich, P.R., Garcia, T. (2015). Intraindividual Differences in Students Motivation and Self Regulated Learning. Zeitschrift für Pädagogische Psychologie, 2, 1-22 
TAZKIYA (Journal of Psychology), 9(2), 2021

Poerwandari. 2011. Pendekatan Kualitatif dalam Penelitian Psikologi. LPSP3 Psikologi UI.

Pralaska, F.S. (2017). Johari Window Games Sebagai Sarana Untuk Menghargai Diri di Siswa SMP. Prosiding Konferensi Pendidikan Nasional, 202-211

Prasetyaningrum, S. (2019). Konsep diri dengan regulasi diri dalam belajar pada siswa SMA. Jurnal Ilmiah Psikologi Terapan, 7(2), 171-183

Pritaningrum, M. \& Hendriani, W. (2013). Penyesuaian diri remaja yang tinggal di Pondok Pesantren Modern Nurul Izzah Gresik pada tahun pertama. Jurnal Psikologi Kepribadian dan Sosial, 2(3), 234240.

Rachmawati, I.K. (2010). Manajemen sumber daya manusia. CV Andi Offset

Rao, R.B. (2012). A Study of Academic Stress and Adjustment Styles of Teacher Trainees. Unpublished Thesis, Education, Acharya Nagarjuna University, retrieved from http://shodhganga.inflibnet.ac.in/handle/10603/8093 on March 3, 2018

Republika. 2013. Boarding School Makin Diminati. http//:www. Republika.co.id. (Diunduh tanggal 26 Januari 2020).

Romera, E.M. (2017). A Review of Self Regulated Learning: Six Models and Four Direction for Research. Frontiers in Psychology, 8, 1-28.

Rooij, E.C.M. (2017). First year university students academic success: The importance of academic adjustment. Eur J Psychol Educ. 219 (3). 158-170

Rumahorbo, A.W. (2014). Hubungan antara konsep diri akademik dengan self regulated learning pada mahasiswa penghuni asrama mahasiswa Universitas Sumatera Utara. Program Studi Psikologi Universitas Sumatera Utara

Rusdin. (2017). Pendidikan Dan Pelatihan Sebagai Sarana Peningkatan Kompetensi Guru Di Smp Negeri 02 Linggang Bigung. Jurnal Administrative Reform, 5(4), 200-212

Santrock, J. W. (2010). Adolescence: Perkembangan Remaja. Jakarta: Edisi 11 Erlangga.

Schmitz, B., Schmidt, M., Landmann, M., Speil, C. (2011). New Developments in the Field of Self regulated learning. Journal of Psychology, 215 (3), 153-156

Schneiders, A. A. (1964). Personal adjustment and mental health. New York, Amerika Serikat : Holt, Reinhart \& Winston Inc.

Schneiders, A. (2010). Personal Adjusment and Mental Health. New York: Rinehart and Winston, Inc.

Schunk, D.H., Pintrich, P.R., \& Meece, J.L. (2012). Motivation in education: Theory, research, and application. New Jearsey: Pearson Prentice Hall.

Setyawan, I. (2012). Hubungan antara penyesuaian diri dengan prokrastinasi akademik siswa sekolah berasrama SMP N 3 Peterongan Jombang. Jurnal Psikologi Undip, 8(2), 156-167.

Soebahar, A.H. (2013). Modernisasi Pesantren Studi Transformasi Kepemimpinan Kiai dan Sistem Pendidikan Pesantren. Yogyakarta: Lkis 
Sugiyono. (2015). Metode Penelitian Kuantitatif, Kualitatif Dan R \& D. Bandung: Alfabeta.

Sulton, M., Khusnuridlo, M. (2010). Manajemen Pondok Pesantren Dalam Prespektif Global. Yogyakarta: Laksbang Pres Sindo

Sunyanto, D. (2012). Manajemen sumber daya manusia: Jakarta: CAPS

Tafsir.A. (2011). Ilmu Pendidikan dalam Perspektif Islam. Bandung: Remaja Rosdakarya.

Usman, M.I. (2013). Pesantren Sebagai Lembaga Pendidikan Islam. Jurnal Al Hikmah, 15(1), 103

Wentzel, K.R., \& Watkins, D.E. (2012). Peer relationships and collaborative learning as contexts for academic enablers. School Psychology Review, 31, 366-377

Woolfolk, A.E., Winne, P.H., \& Perry, N.E., (2010). Educational Psychology. Allyn and Bacon.

Yasmadi. (2015). Modernisasi Pesantren Kritik Nurcholis Madjid Terhadap Pendidikan Islam Tradisional. Ciputat Press

Yuniar, M., Abidin, Z. \& Astuti, T.P. (2014). Penyesuaian akademik santri putri terhadap kehidupan pesantren: studi kualitatif pada Madrasah Takhasusiah Pondok Pesantren Modern Islam Assalam Surakarta. Jurnal Psikologi Undip, 2, 10-17.

Zakiyah, N., Hidayati, F. N. R., Setyawan, I. (2013). Hubungan antara penyesuaian diri dengan prokastinasi akademik siswa sekolah berasrama smp n 3 petrongan jombang. Jurnal Psikologi Undip, $8(2), 20-35$ 